\title{
1 Microcystin in aquatic food webs of the Baltic and 2 Chesapeake Bay regions.
}

3 Paul A. Bukaveckas ${ }^{1 *}$, Jūratė Lesutienè ${ }^{2}$, Zita R. Gasiūnaité ${ }^{2}$, Linas Ložys ${ }^{3}$, Irina Olenina ${ }^{4}$,

4 Renata Pilkaityte ${ }^{2}$, Žilvinas Pūtys $^{3}$, Spencer Tassone ${ }^{1}$ and Joseph Wood ${ }^{5}$.

5 1. Virginia Commonwealth University, Center for Environmental Studies and Department of

6 Biology, Richmond, VA.

7 2.Open Access Centre for Marine Research, Klaipeda University, Klaipèda, Lithuania

8 3. Laboratory of Marine Ecology, Nature Research Centre, Vilnius, Lithuania

9 4. Department of Marine Research, Environmental Protection Agency of Lithuania, Klaipeda, 10 Lithuania.

11 5. Chesapeake Bay Foundation, Richmond, VA.

12 *Corresponding Author (pabukaveckas@vcu.edu)

13

Submitted for Review 
18 Abstract

19 We undertook a comparative study of the James River Estuary, a sub-estuary of Chesapeake

20 Bay, and the Curonian Lagoon, a sub-estuary of the Baltic Sea, to better understand the factors

21 that determine the presence and persistence of algal toxins in food webs. Over a 2-year period,

22 we measured microcystin concentrations in water, sediment and biota (fish and shellfish) at both

23 sites. Across both food webs we found highest levels of microcystin among consumers of

24 suspended particulate matter, including planktivorous fishes and filter-feeding shellfish, and

25 lower levels of toxin among piscivores, scavengers and benthic omnivores. Despite similar

26 levels of microcystin in the water column at the two sites, we observed higher toxin levels in fish

27 and sediments of the Curonian Lagoon. We attribute this difference to the legacy of prior toxic

28 cyanobacteria blooms in the Curonian Lagoon and hydrologic factors that result in a

29 predominance of autochthonously-derived organic matter in the sediments at this site. Our

30 results suggest that a consideration of species-specific differences in feeding habits, and organic

31 matter sources supporting food webs are important to understanding the accumulation and

32 persistence of algal toxins in food webs and should therefore be considered in assessment of

33 risks to aquatic biota and human health. 
Nutrient enrichment of coastal waters has resulted in an increase in the frequency, intensity and duration of harmful algal blooms (HABs; Paerl et al. 2009, Heisler et al. 2011, O’Neil et al. 2012, Michalak et al. 2013, Paerl and Otten 2013a). Harmful algae produce toxins which have deleterious effects on aquatic biota and pose a human health concern (Miller et al. 2010, Poste et al. 2011, Corbel et al. 2014, Ibelings et al. 2014). Human health threats arise from direct contact with waters containing harmful algae, and from ingestion of toxins via contaminated drinking water, crops (via irrigation), and fish-shellfish. Among the most widely occurring harmful algae are cyanobacteria, which are commonly found in fresh-brackish waters, including the Baltic Sea and tributaries of the Chesapeake Bay (Karjalainen et al. 2007, Anderson et al. 2008, Mazur-Mazec et al. 2013, Wood and Bukaveckas 2014). Cyanobacteria produce a variety of toxins, the most common of which is microcystin, a hepatotoxin known to cause damaging health effects on humans and biota (Corbel et al. 2014, Rastogi et al. 2014). Microcystin accumulates in the tissues of a wide range of aquatic consumers (Lehman et al. 2010, Wood and Bukaveckas 2014). Physiological responses of organisms may include liver damage, behavioral changes, reduced fecundity and mortality (Corbel et al. 2014, Rastogi et al. 2014). The toxin is thought to be a chemical defense against predators, though the environmental factors favoring its occurrence are poorly understood (Davis et al. 2009, Paerl and Otten 2013b, Boopathi and Ki 2014). The World Health Organization has established guidelines for consumption and exposure (WHO 2003); however, monitoring is often lacking, thus limiting our ability to assess environmental and human health risks. There is a need to better understand the factors governing the presence of algal toxins in aquatic biota, particularly among commercially and recreationally important fish and shellfish.

The presence and persistence of algal toxins in food webs is governed by a variety of factors including the frequency, timing and intensity of HAB events, food web dependence on autochthonous production, and factors governing the fate and storage of toxins (e.g., sedimentation, degradation, washout). Algal toxins are not known to biomagnify (Ibelings et al.

62 2005, Kozlowsky-Suzuki et al. 2012), therefore highest concentrations (per unit mass) are found 63 in the algae themselves, with diminishing concentrations along the food chain. At higher trophic 64 levels, toxin concentrations are related to the proportion of consumer diet derived from algal 
65 biomass (Wood et al. 2014). Higher toxin concentrations would be expected among suspension

66 feeders, including planktivorous fish and benthic filter-feeders, in comparison to predators and

67 benthic omnivores, due to greater ingestion of toxic algae. Species-specific attributes such as

68 depuration and ontogenetic shifts in feeding, are also important in determining variation in toxin

69 levels among consumers. Few studies have characterized algal toxins at the food-web scale, thus

70 limiting cross-system comparisons which are needed to disentangle these various factors and

71 improve understanding of risks to aquatic biota and human exposure.

In this paper, we present a comparative analysis of microcystin in the food webs of the

73 James River Estuary, a sub-estuary of Chesapeake Bay, and the Curonian Lagoon, a sub-estuary

74 of the Baltic Sea. These sites were selected on the basis of having well-described food webs, a

75 known history for the occurrence of toxic cyanobacteria and the presence of commercial and recreational fisheries (Wood et al. 2014, Lesutiene et al. 2014). We characterized microcystin concentrations in water, sediment, and fish-shellfish tissues to better understand how fish feeding

78 habits, and the history of cyanobacteria blooms, effect toxin concentrations at higher trophic levels. Microcystin data for fish tissues were also used to assess potential human health risks.

\section{Methods}

This study was conducted in the tidal freshwater segment of the James (JTF) and the northern (Lithuanian) portion of the Curonian Lagoon (NCL) which are located in the midAtlantic region of the United States and northern Europe, respectively (Figure 1; Table 1). The two sites are similar in being eutrophic with summer chlorophyll-a (CHLa) typically exceeding $30 \mu \mathrm{g} \mathrm{L}^{-1}$ and maximum values over $100 \mu \mathrm{g} \mathrm{L}^{-1}$ (Bukaveckas et al. 2011, Bukaveckas and

87 Isenberg 2013, Wood and Bukaveckas 2014, Zilius et al. 2014). The sites differ in their relative contributions of cyanobacteria to phytoplankton biomass. In the James, phytoplankton communities are dominated by diatoms and chlorophytes, with a small contribution from cyanobacteria ( $<10 \%$ of biomass) and low levels of cyanotoxins (Wood et al. 2014). Phytoplankton communities in the Curonian Lagoon are characterized by blooms of cyanobacteria during summer, low-wind conditions (Zilius et al. 2014). Stable isotope studies

93 have shown that cyanobacteria biomass is rapidly exploited by a wide range of consumers in the 94 Lagoon (Lesutiene et al. 2014). 


\section{Sampling - Curonian Lagoon}

Water, sediment and fish-shellfish samples were collected from the Curonian Lagoon during 2013-2014. Near-surface ( 1 m) water samples were obtained semi-monthly during August-October 2013 and May-October 2014 at 4 stations distributed throughout the northern half of the lagoon (total $\mathrm{N}=105$ ). Water samples were analyzed for CHLa and microcystin. In addition to data collected for this study, we provide historical data (2006-2014) on CHLa and phytoplankton community composition collected semi-monthly at a station located in the northern half of the lagoon by the Department of Marine Research of the Environmental Protection Agency of Lithuania. Sediment samples were collected in May, August and October 2014 to represent pre-, peak- and post- bloom conditions, respectively. Three replicate cores were collected at each of two sites representing the dominant substrate types of the lagoon (silt vs. sand; Zilius et al. 2014). Cores were obtained using plexiglass tubes mounted in a hand corer. The cores were sectioned and the top $(0-0.5 \mathrm{~cm})$, middle $(1-2 \mathrm{~cm})$ and bottom $(5-10 \mathrm{~cm})$ sections were analyzed for dry mass $(\mathrm{dm}), \mathrm{CHLa}$ and microcystin (total $\mathrm{N}=62$ ).

Fish and mollusks were sampled in September 2013, May 2014 and August 2014 to represent post-, pre- and peak- bloom conditions, respectively. Sampling was conducted along the eastern shore of the lagoon (near Vente cape; Figure 1). Six fish species belonging to three ecologic groups were selected: predatory Pike-perch (Sander lucioperca), benthic omnivores European Perch (Perca fluviatilis), Roach (Rutilus rutilus) and Freshwater Bream (Abramis brama), and planktivorous Sabre Carp (aka Sichel; Pelecus cultratus) and Bleak (Alburnus alburnus). Bream, Roach, Perch and Pikeperch are the most important commercial fish in the Curonian Lagoon (comprising $\sim 80 \%$ of landings). For Perch and Roach we sampled both adults and juveniles to assess ontogenetic shifts in microcystin exposure. Adult fish were caught using gillnets deployed at 2-4 m depth. Sabre Carp were obtained from commercial fisherman. Juvenile fish and Bleaks were caught using a beach seine at up to $1 \mathrm{~m}$ depth. Microcystin analysis was performed on dorsal muscle and liver tissues. The dominant benthic filter-feeders, Zebra Mussels (Dreissena polymorpha) and Painter's mussel (Unio spp.), were collected from fish nets, washed and placed overnight for gut content evacuation. Whole soft tissues of small Zebra Mussels $(1.0 \pm 0.1 \mathrm{~cm})$ and foot and mantle tissues of larger Zebra Mussels $(\sim 2 \mathrm{~cm})$ and 
124 Painter's mussel $(6-8 \mathrm{~cm})$ were dissected for microcystin analysis. A total of 566 fish and 40 mollusk samples were analyzed.

\section{Sampling - James River}

Sampling of water, sediment and biota from the James River Estuary was conducted in 2012-2013 as previously described in Wood et al. (2014). Near-surface (1 m) water samples were collected $\sim$ weekly from May through November 2012 at three sites (total $N=72$ ). Sediment samples were collected monthly from May to October 2012 at each of three near-shore sites (depth $<2 \mathrm{~m}$ ). Sediments from these sites were typical for the area being dominated by silty deposits. Triplicate samples of surficial sediments $(0-2 \mathrm{~cm})$ were analyzed for dry mass, CHLa and microcystin (total $\mathrm{N}=54$ ). Fish sampling targeted abundant and ecologically important taxa including planktivores (juvenile American Gizzard Shad (Dorosoma cepedianum), Threadfin Shad (D. petenense), and Atlantic Menhaden (Brevoortia tyrannus)), benthivores (juvenile Blue Catfish (Ictalurus furcatus) and adult American Gizzard Shad) and piscivores (Blue Catfish $>40$ $\mathrm{cm}$ ). We also sampled the common wedge clam (Rangia cuneata), which is the dominant benthic filter-feeder, and Blue Crabs (Callinectes sapidus) as the latter are a pathway for human exposure. Approximately 10-15 individuals of each were obtained monthly during May-October 2012 with additional samples collected in March 2013 to assess toxin levels in over-wintering populations. Fish were obtained by electrofishing (low and high frequency) along multiple transects located in proximity to the water monitoring locations. Blue Crabs were obtained from multiple crab pots deployed in proximity to fish sampling areas. Rangia were collected from a near-shore site using oyster tongs and held in deionized water for $48 \mathrm{~h}$ to allow for clearance of gut contents. Muscle and liver (fish) or viscera (crabs, clams) were surgically removed. For juvenile fishes, individuals were occasionally pooled (2-3 per sample) to obtain sufficient material for microcystin analysis. Microcystin analysis was performed on a total of 268 fish and 126 shellfish samples.

\section{Analytical Methods}

CHLa (water and sediments) was measured by extraction in $90 \%$ buffered acetone and fluorometric analysis (VCU) and by extraction in ethanol and spectrophotometric analysis (Department of Marine Research, DMR). Phytoplankton samples from the DMR long-term 
153 monitoring station were analyzed by the inverted microscopy counting technique (Olenina et al. 2006, Jaanus et al. 2011). All microcystin samples were analyzed at Virginia Commonwealth University (VCU). Our analysis of water, sediment and tissue samples was based on ELISA, a method which offers several advantages for studies with large sample sizes, such as food web assessments. Commercially available kits allow for efficient sample processing while providing high sensitivity at low levels of microcystin relevant to ecotoxicological studies (ADDA ELISA Kit; detection limit $0.05 \mu \mathrm{g} \mathrm{L}^{-1}$; Abraxis; Warminster, PA). The assay measures numerous forms of free microcystin using polyclonal antibodies, which allows for quantification of all reactive microcystin variants in a single assay (reported as microcystin-LR equivalents). The assay measures only free microcystin and does not account for the presence of protein (covalently)bound microcystin. Protein-bound microcystin has lower bioavailability, and therefore the extractable fraction (as measured by ELISA) may be a better indicator for human health concerns, though this has not been established experimentally (Ibelings and Chorus 2007, Neffling et al. 2010). It has been reported that for tissue samples, ELISA results in a higher proportion of positive detections at low concentrations $\left(<10 \mathrm{ng} \mathrm{g}^{-1} \mathrm{dm}\right)$ compared to mass spectrometry-based methods (Geis-Asteggiante et al. 2011). It is unclear whether this discrepancy is due to false positives from cross-reaction with non-microcystin metabolites during ELISA, or if these represent findings below the detection limit for mass spectrometry. In our dataset, non-zero values in this range $\left(<10 \mathrm{ng} \mathrm{g}^{-1} \mathrm{dm}\right)$ represented 7\% (James) and 5\% (Curonian Lagoon) of the samples analyzed.

To measure total microcystin in water, samples were thawed and refrozen two times (as 175 from cells (Silva-Stenico et al. 2009). All water samples exceeding 0.15 ppt were pre-treated by passing through a resin column to remove interference from salinity (as per manufacturer's recommendations). Samples of tissue were dissected immediately upon collection and dried in

178 preparation for extraction (see below). We determined both the wet and dry weight of each 179 sample. Microcystin concentrations were expressed per unit of dry mass; for Estimated Daily Intake, we used concentrations per unit of wet weight (see below). For extraction, we used 0.5 to $1811 \mathrm{~g} \mathrm{dm}$ of liver or muscle tissue, with the exception of small fishes (bleak, juvenile Yellow Perch and juvenile roach), for which liver tissues samples were 0.1 to $0.3 \mathrm{~g} \mathrm{dm}$. 
To extract microcystin from tissues and sediment, samples were dried at $60^{\circ} \mathrm{C}$ for $48 \mathrm{~h}$, ground with a mortar and pestle, and extracted in 75\% aqueous methanol for $24 \mathrm{~h}$ (Babica et al. 2006, Wilson et al. 2008, Garcia et al. 2010). Extracts were centrifuged and supernatant collected. Subsamples were diluted with deionized water such that samples to be run on the ELISA plate contained $<5 \%$ methanol. Plates were read on an ELISA plate reader at $450 \mathrm{~nm}$. For each 96-well plate, 8 standards and all samples were run in duplicate. The mean standard error among duplicate water samples was $0.02 \mu \mathrm{g} \mathrm{L}^{-1}$; the mean standard error for duplicate tissue samples was $0.021 \mu \mathrm{g} \mathrm{g} \mathrm{dm}^{-1}$. Average recovery from positive internal controls was $98 \pm 4 \%$. Average recoveries from spiked samples were as follows: water-seston $=94 \pm 6 \%$, sediment $=$ $90 \pm 11 \%$, shellfish viscera $=67 \pm 7 \%$, fish liver $=74 \pm 15 \%$ and fish muscle $=89 \pm 12 \%($ Wood et al. 2014). The method used in our study (ADDA ELISA with methanol extraction) was shown to have the best recovery among four sample processing methods, with low matrix effects even at concentrations less than $10 \mathrm{ng} \mathrm{g}^{-1} \mathrm{dm}$ (Preece et al. 2015).

\section{Statistical Analysis}

Microcystin concentrations in tissues are not normally distributed due to the occurrence of rare, high values. Therefore data for individual species are presented as both means and medians, the former reflecting the influence of the tail of the distribution, and the latter providing a better indicator of central tendency. For statistical analysis, the data were log-transformed. A 2-way ANOVA was used to determine what proportion of the variation in tissue microcystin concentrations among individuals could be accounted for by site (James River, Curonian Lagoon) and feeding group (planktivores, benthic omnivores and predators). One-way ANOVA of log-transformed data was used to test for significant differences in tissues microcystin concentrations across months (seasonal effects) and between juveniles and adults of the same species (ontogenic effects).

\section{Estimated Daily Intake}

To assess human health risks associated with consumption of fish and shellfish, we compared Estimated Daily Intake (EDI) with the Tolerable Daily Intake (TDI) proposed by the World Health Organization (2003). The TDI value $\left(0.04 \mu \mathrm{g} \mathrm{MC} \mathrm{kg}^{-1}\right.$ body weight $\left.\mathrm{d}^{-1}\right)$ is an allowable daily rate of toxin ingestion based on the consumer body mass. For a body mass of 60 
$212 \mathrm{~kg}$, the ingestion threshold is $2.4 \mu \mathrm{g} \mathrm{MC} \mathrm{d}^{-1}$. For comparison, we derived EDI values based on 213 measured toxin concentrations in fish-shellfish and an assumed serving size of $300 \mathrm{~g}$ wet mass

214 (wm; Garcia et al. 2010). EDIs were derived for a single (daily) serving and, for long-term

215 exposure, based on one serving per week. Tissue concentrations were for muscle, except in Blue 216 Crabs for which consumption was based on $80 \%$ muscle tissue and $20 \%$ viscera.

\section{Results}

The Curonian Lagoon experienced recurring algal blooms in 2006-2014 during periods of low discharge and warm water temperature (Figure 2). A large Microcystis bloom occurred in 2006 when biomass reached $5.3 \mathrm{mg} \mathrm{L}^{-1}$ and comprised $60 \%$ of total cyanobacteria biomass. A prior study reported that microcystin concentrations reached $134 \mu \mathrm{g} \mathrm{L}^{-1}$ in that year

223 (Paldaviciene et al. 2015). The long-term data presented here shows that in subsequent years, cyanobacteria blooms were dominated by Anabaena (now Dolichospermium) and Planktothrix, with Microcystis accounting for $\sim 5 \%$ of biomass. Over the 2 -years when the food-web study was conducted, average CHLa concentrations were higher in the Curonian Lagoon $(73 \pm 18 \mu \mathrm{g}$ $\left.\mathrm{L}^{-1}\right)$ relative to the James $\left(27 \pm 2 \mu \mathrm{g} \mathrm{L}^{-1}\right)$, whereas microcystin concentrations were similar $(0.30$ \pm 0.07 and $0.32 \pm 0.04 \mu \mathrm{g} \mathrm{L}^{-1}$, respectively) at the two sites (Figure 3). An exception was the bloom event occurring in the Curonian Lagoon on September 52014 when CHLa concentrations exceeded $100 \mu \mathrm{g} \mathrm{L}^{-1}$ and microcystin concentrations reached $4.34 \mu \mathrm{g} \mathrm{L}^{-1}$ at one of the 4 stations. Microcystin concentrations were otherwise less than $1 \mu \mathrm{g} \mathrm{L}{ }^{-1}$ in both the James River Estuary and Curonian Lagoon.

In the Curonian Lagoon, substrate type (silty vs. sandy) was an important determinant of sediment microcystin and CHLa content (Figure 4). In silty sediments (southern lagoon, Figure 1), microcystin concentrations averaged $26 \pm 7 \mathrm{ng} \mathrm{g}^{-1} \mathrm{dm}$ (mean across months), whereas at the 236 sandy site (northern lagoon), sediment microcystin concentrations were $\sim 1 \mathrm{ng} \mathrm{g}^{-1} \mathrm{dm}$. Higher microcystin concentrations in silty sediments corresponded to elevated CHLa content (mean = $192 \pm 13 \mu \mathrm{g} \mathrm{g}^{-1} \mathrm{dm}$ ) relative to sandy sediments (mean $=14 \pm 2 \mu \mathrm{g} \mathrm{g}^{-1} \mathrm{dm}$ ). In silty sediments,

239 stratigraphic analysis revealed higher microcystin levels at $1-2 \mathrm{~cm}$ depth $\left(39 \pm 18 \mathrm{ng} \mathrm{g}^{-1} \mathrm{dm}\right)$ 
$241{ }^{1} \mathrm{dm}$ ) sediments (see Supplemental Information). Areal values for total microcystin (top $10 \mathrm{~cm}$

242 of sediment) were 323 and $122 \mu_{\mathrm{g} \mathrm{m}}^{-2}$ (silty and sandy, respectively) as the lower mass density

243 of silty $\left(12 \mathrm{~kg} \mathrm{dm} \mathrm{m}^{-2}\right)$ vs. sandy $\left(125 \mathrm{~kg} \mathrm{dm} \mathrm{m}^{-2}\right)$ sediments partially offset higher microcystin

244 concentrations (per unit mass) in silty sediments. In the James, sediment microcystin

245 concentrations ranged from below detection limits $\left(0.1 \mathrm{ng} \mathrm{g}^{-1} \mathrm{dm}\right.$; May, June and October) to 2.6

$246 \pm 0.1 \mathrm{ng} \mathrm{g}^{-1} \mathrm{dm}$ (September). Seasonal patterns of microcystin concentrations corresponded to

247 patterns in sediment CHLa concentrations, which ranged from 1 to $21 \mu \mathrm{g} \mathrm{g}^{-1} \mathrm{dm}$, with peak

248 values in September. Overall, the mean microcystin concentration of Curonian Lagoon

249 sediments (17 $\pm 4 \mathrm{ng} \mathrm{g}^{-1} \mathrm{dm}$ based on silty and sandy sites) was 40 -fold higher than the mean

250 value for the James Estuary $\left(0.4 \pm 0.2 \mathrm{ng} \mathrm{g}^{-1} \mathrm{dm}\right)$.

Higher microcystin content of Curonian Lagoon sediments corresponded to higher

252 microcystin concentrations among fish and shellfish relative to those observed in the James

253 River (Figures 5 and 6). Across all feeding types, the average liver microcystin concentration

254 among Curonian fishes (mean $=193 \pm 9 \mathrm{ng} \mathrm{g}^{-1} \mathrm{dm}$; median $=144 \mathrm{ng} \mathrm{g}^{-1} \mathrm{dm}$ ) was significantly

255 greater than the mean concentration among James River fishes (mean $=112 \pm 14 \mathrm{ng} \mathrm{g}^{-1} \mathrm{dm}$;

256 median $=33 \mathrm{ng} \mathrm{g}^{-1} \mathrm{dm}$ ). A two-way ANOVA revealed that both Site (James, Curonian) and

257 Feeding Group (Benthic, Predator and Planktivore) were significant factors accounting for

258 variation in microcystin concentrations $\left(\mathrm{R}^{2}=0.27, \mathrm{~F}=45.1 ; \mathrm{p}<0.0001 ; \mathrm{N}=635\right)$. Benthivores

259 of the Curonian Lagoon (Freshwater Bream, juvenile European Perch, and juvenile and adult

260 Roach; range of medians $=143-197 \mathrm{ng} \mathrm{g}^{-1} \mathrm{dm}$ ) exhibited liver microcystin concentrations that

261 were 5- to 10- fold higher than benthivores of the James Estuary (juvenile Blue Catfish and adult

262 American Gizzard Shad; medians $=35$ and $10 \mathrm{ng} \mathrm{g}^{-1} \mathrm{dm}$, respectively). Among piscivores,

263 fishes of the Curonian Lagoon (Zander median $=175 \mathrm{ng} \mathrm{g}^{-1} \mathrm{dm}$, adult European Perch median =

$264113 \mathrm{ng} \mathrm{g}^{-1} \mathrm{dm}$ ) had 6-fold greater liver microcystin concentrations than adult Blue Catfish (James

265 River; median $=25 \mathrm{ng} \mathrm{g}^{-1} \mathrm{dm}$ ). Blue Crabs (James River) were included in this predatory group

266 and showed higher levels of microcystin (viscera) relative to Blue Catfish (median $=80 \mathrm{ng} \mathrm{g}^{-1}$

$267 \mathrm{dm}$ ). Among planktivores, highest liver microcystin concentrations were found in Bleak

268 (Curonian Lagoon; median $=312 \mathrm{ng} \mathrm{g}^{-1} \mathrm{dm}$ ). Concentrations were otherwise similar among

269 juvenile American Gizzard Shad (James; median = $103 \mathrm{ng} \mathrm{g}^{-1} \mathrm{dm}$ ), Atlantic Menhaden (James;

270 median $\left.=95 \mathrm{ng} \mathrm{g}^{-1} \mathrm{dm}\right)$, Threadfin Shad (James; median = $130 \mathrm{ng} \mathrm{g}^{-1} \mathrm{dm}$ ) and Sabre Carp 
271 (Curonian Lagoon; median $=135 \mathrm{ng} \mathrm{g}^{-1} \mathrm{dm}$ ). Among benthic filter-feeders, Painter's and Zebra

272 Mussels (Curonian Lagoon; median = 401 and $224 \mathrm{ng} \mathrm{g}^{-1} \mathrm{dm}$, respectively) had 10-fold higher

273 microcystin levels (whole-body) relative to Wedge Clams found in the James $\left(25 \mathrm{ng} \mathrm{g}^{-1} \mathrm{dm}\right)$.

274 Seasonal variation in tissue microcystin concentrations was observed in both systems,

275 with highest concentrations generally occurring in Summer or Fall, and lowest levels observed in

276 Spring (Figure 7). Statistically significant seasonal differences were observed for Perch

277 (juveniles), Roach, Bream, Gizzard Shad (juveniles), Blue Catfish and Threadfin Shad. Greatest

278 seasonal variation occurred among planktivores in the James (Threadfin Shad and juvenile

279 American Gizzard Shad) which exhibited 5-10 fold higher liver concentrations in Summer.

280 Microcystin levels in juvenile European Perch were found to be significantly higher than in adults $\left(\right.$ mean $=192 \pm 21 \mathrm{ng} \mathrm{g}^{-1} \mathrm{dm}$ and $132 \pm 10 \mathrm{ng} \mathrm{g}^{-1} \mathrm{dm}$, respectively; $\mathrm{F}=5.05, \mathrm{p}=0.027, \mathrm{~N}=$ 94). This likely reflects ontogenic shifts in diet from benthic omnivory as juveniles to piscivory as adults. A similar pattern was observed among American Gizzard Shad in the James with a shift from high microcystin in planktivorous juveniles (mean $=247 \pm 101 \mathrm{ng} \mathrm{g}^{-1} \mathrm{dm}$ ) to lower microcystin in detritivorous adults (mean $=38 \pm 9 \mathrm{ng} \mathrm{g}^{-1} \mathrm{dm}$; Wood et al. 2014, Schaus et al. 2002). No significant differences in microcystin content were found between juvenile and adult

287 Roach $(\mathrm{F}=0.01, \mathrm{p}=0.9, \mathrm{~N}=68)$.

Results of the EDI analysis for muscle tissue showed that while single servings of some

fish exceeded the TDI threshold, the long-term exposure, based on one serving per week, did not

290 (Table 2). Among fishes of commercial importance in the Curonian Lagoon, EDI for single servings of Freshwater Bream (3.4 $\left.\mu \mathrm{g} \mathrm{MC} \mathrm{d}^{-1}\right)$, Roach $\left(3.0 \mu \mathrm{g} \mathrm{MC} \mathrm{d}^{-1}\right)$ and Sabre Carp (3.7 $\mu \mathrm{g}$

$\left.292 \mathrm{MC} \mathrm{d}^{-1}\right)$ exceeded the TDI threshold $\left(2.4 \mu \mathrm{g} \mathrm{MC} \mathrm{d}^{-1}\right)$. In the James Estuary, single servings were 293 below EDI values $\left(<0.4 \mu \mathrm{g} \mathrm{MC} \mathrm{d}^{-1}\right)$ with the exception of Blue Crabs $\left(2.3 \mu \mathrm{g} \mathrm{MC} \mathrm{d}^{-1}\right)$. The 294 higher value for Blue Crabs was due to the assumption that $20 \%$ non-muscle tissue was ingested, 295 and because viscera contained high levels of microcystin $\left(24 \pm 4 \mathrm{ng} \mathrm{g}^{-1} \mathrm{wm}\right)$ relative to muscle (4 $\left.296 \pm 2 \mathrm{ng} \mathrm{g}^{-1} \mathrm{wm}\right)$. The long-term exposure EDI values were $<0.8 \mu \mathrm{g} \mathrm{MC} \mathrm{d}^{-1}$ for fish and shellfish 297 from both systems, with the exception of Bleak (a non-commercial species). Bleak exhibited the 298 highest liver microcystin concentrations and its muscle concentrations were 6-fold higher than 299 the next closest fish (juvenile Roach). 


\section{Discussion}

Our prior work showed that variable levels of algal toxins among fishes of the James River were linked to their dietary habits in that planktivorous fishes were found to have higher concentrations of microcystin relative to benthic omnivores and piscivores (Wood et al. 2014). These differences were correlated with higher CHLa in planktivore gut contents due to feeding on suspended particulate matter. Results from the present study comparing food webs of the James Estuary and Curonian Lagoon support this finding as we found statistically significant differences among feeding groups, with highest microcystin concentrations among suspension feeders such as the Painter's Mussel (Curonian Lagoon), Bleak (Curonian Lagoon) and juvenile American Gizzard Shad (James River). Lowest toxin concentrations were observed in piscivorous (adult) Blue Catfish, benthivorous (adult) American Gizzard Shad and Wedge Clams. These findings along with related studies (Wilson et al. 2008) suggest that a trophic perspective based on consumer feeding habits provides a basis for assessing risk to fisheries and human health posed by algal toxins.

Our comparative study revealed that the two systems exhibited similar and low levels of microcystin in the water column during the period of study, whereas microcystin levels were higher in sediments of the Curonian Lagoon. A prior study of the Curonian Lagoon had shown elevated levels of microcystin in Zebra Mussels over several years following the large Microcystis bloom in 2006 (Paldaviciene et al. 2015). Our findings expand on these results showing that elevated microcystin levels have persisted 7-8 years after the bloom event and extend to a wide range of consumers including benthivorous, planktivorous and piscivorous fishes. The persistence of lipophilic toxicants in sediments and food webs is well documented (e.g., mercury, PCBs). The low lipophilicity of microcystin and its depuration from biota would be expected to result in transient occurrence in biota during toxin-producing blooms. Our results for the Curonian Lagoon suggest that this is not the case and raise concerns for chronic exposure for biota and long-term human health risks. The low levels of microcystin in the water column $\left(<5 \mu \mathrm{g} \mathrm{L}^{-1}\right.$ during the period of this study) are unlikely to cause mortality effects on biota, which are typically observed at much higher concentrations (100's - 1000's $\mu^{g} \mathrm{~L}^{-1}$; Smith et al. 2008). However, little is known regarding sub-lethal effects and chronic, low-level exposure to microcystin in biota or humans. 
We hypothesize that elevated levels of microcystin in the food web of the Curonian Lagoon is due to the persistence of the toxin in sediments. Consumer exposure occurs as a result of detritivory (by benthic omnivores) and, for suspension feeders, following periodic resuspension of sediments during wind-driven mixing events (Paldaviciene et al. 2015). The predominance of autochthonously-derived organic matter in the sediments of the Curonian Lagoon may be a contributing factor to the occurrence of high microcystin concentrations in sediments. Sources of particulate organic matter to the lagoon are dominated by internal production with phytoplankton accounting for 69\% of total inputs (Galkus and Jokšas 1997, Daunys et al. 2006). Allochthonous contributions are small because the principal tributary (Nemunas River) is a regulated, lowland river which drains peaty-sandy soils and carries low suspended particulate matter (Mikhailova and Zaromskis 2013). In addition, the Curonian Lagoon has a low hydrological loading factor (ratio of contributing area to surface area $=63$ ) which, combined with the low sediment delivery (Daunys et al. 2006) translates to a loading rate of $278 \mathrm{~g} \mathrm{~m}^{-2} \mathrm{y}^{-1}$. By comparison, the annual areal load for the tidal fresh segment of the James $\left(1501 \mathrm{~g} \mathrm{~m}^{-2} \mathrm{y}^{-1}\right)$ is approximately five times higher (average for 2012-2014 based on our weekly monitoring of TSS and daily discharge recorded by the US Geological Survey). This reflects the large and mountainous watershed of the James (hydrologic loading factor $=184$ ) which has a high sediment yield (TSS $>200 \mathrm{mg} \mathrm{L}^{-1}$ during high discharge events; Smock et al. 2005, Wood et al. 2016).

Our contention is that in coastal waters experiencing large sediment loads, inputs of allochthonous particulate matter will dilute autochthonously-derived organic matter thereby reducing long-term exposure to algal toxins. In systems dominated by autochthonous sources of particulate matter, such as the Curonian Lagoon, there is less dilution of algal toxins resulting in long-term exposure for consumers and persistence in food webs. Stratigraphic data from our silty site showed that sediments enriched with microcystin have been partially buried since the 2006 bloom event, with peak microcystin concentrations observed 1-2 $\mathrm{cm}$ below the sedimentwater interface. Other studies have also documented the presence of microcystin in sediments (Misson et al. 2012, Takahashi et al. 2014), though questions about persistence and bioavailability remain. Based on the relative contributions of silty (44\%) and sandy (55\%) areas in the Lithuanian portion of the Curonian Lagoon (Zilius et al. 2014) we estimate a total mass of 
$36084 \mathrm{~kg}$ of microcystin in the $0-10 \mathrm{~cm}$ sediment layer. By comparison, the mass of microcystin in 361 the water column during the 2006 Microcystis bloom event was $5380 \mathrm{~kg}$ (based on a mean 362 concentration of $3.43 \mu \mathrm{g} \mathrm{L}^{-1}$ measured at 7 stations; Paldaviciene et al. 2009). Prior research has 363 demonstrated rapid degradation of cyanotoxins associated with sediment deposition in the Baltic 364 Sea (Kankaanpaa et al. 2009). Our data from the Curonian Lagoon support this finding 365 suggesting that the bulk of microcystin degraded or became covalently bonded within the 366 sediment, and therefore not susceptible to conventional extraction techniques (Schmidt et al. 367 2014). Despite this, the small proportion of microcystin residing in the sediments ( $\sim 2 \%$ relative 368 to the mass in the water column in 2006) has resulted in persistent elevated levels of toxin in 369 biota.

370 Our estimates of daily intake suggest that microcystin in fish-shellfish from the James 371 River Estuary and Curonian Lagoon does not pose a human health risk based on current WHO 372 guidelines and an assumed consumption rate of one serving per week. Observed microcystin 373 levels also fell below proposed seasonal and acute tolerable intake values (Ibelings and Chorus 374 2007). Our analysis is based on arithmetic mean values for tissue concentrations; these are more 375 protective of health risks than other indicators of central tendency (e.g., median or geometric 376 mean) because the arithmetic mean is sensitive to the tail of the distribution (i.e., rare, high 377 values). However it is important to note that there is a wide range of toxin concentrations within 378 a population, and therefore individual fish can exceed the recommended guidelines, even for 379 species in which mean concentrations fall below the guidelines.

In conclusion, our comparative study of microcystin in food webs of two coastal, 381 eutrophic waterbodies suggests that a trophic perspective which considers consumer feeding 382 habits and sources of organic matter to waterbodies may be useful in predicting the levels and 383 persistence of algal toxins in food webs. Despite similar levels of microcystin in the water 384 column, we found that microcystin concentrations in the food web and sediments of the 385 Curonian Lagoon were higher than in the James River Estuary. We attribute this difference to a 386 legacy effect of algal blooms occurring prior to this study, coupled with hydrologic factors that 387 result in a predominance of autochthonous organic matter in the sediments of the Curonian 388 Lagoon. 


\section{Acknowledgments}

390 This research was supported in part by funding from the Lithuanian National Science Foundation 391 (award MIP - 037/2014) and the Virginia Department of Environmental Quality. We are

392 grateful to Mindaugas Zilius, Tomas Ruginis and David Hopler for their assistance with field 393 collection of sediments and fish. This paper is contribution \#XX to the Rice Rivers Center. 


\section{References}

Anderson, D. M., Burkholder, J. M., Cochlan, W., Gilbert, P. M., Gobler, C. J., Heil, C.A., Kudela, R. M., Parsons, M. L., Rensel, J. E. J., Townsend, D. W., Trainer, V. L., Vargo, G. A., 2008. Harmful algal blooms and eutrophication: Examples of linkages from selected coastal regions of the United States. Harmful Algae 8, 39-53.

Babica, P., Kohoutek, J., Blaha, L., Adamovsky, O., Marsalek, B., 2006. Evaluation of extraction approaches linked to ELISA and HPLC for analysis of Microcystin-LR, -RR and -YR in freshwater sediments with different organic material contents. Analytical and Bioanalytical Chemistry 385, 1545-1551.

Boopathi, T., Ki, J.-S., 2014. Impact of environmental factors on the regulation of cyanotoxin production. Toxins 6, 1951-1978.

Bresciani, M., Giardino C., Stroppiana D., Pilkaitytė, R., Zilius, M., Bartoli, M., Razinkovas, A., 2012. Retrospective analysis of spatial and temporal variability of chlorophyll-a in the Curonian Lagoon. Journal of Coastal Conservation 16, 511-519.

Bukaveckas, P. A., Isenberg, W. N., 2013. Loading, transformation and retention of nitrogen and phosphorus in the tidal freshwater James River (Virginia). Estuaries and Coasts 36, 12191236.

Bukaveckas, P. A., Barry, L. E., Beckwith, M. J., David, V., Lederer, B., 2011. Factors determining the location of the chlorophyll maximum and the fate of algal production within the tidal freshwater James River. Estuaries and Coasts 34, 569-582.

Corbel, S., Mougin, C., Bouaicha, N., 2014. Cyanobacterial toxins: modes of action, fate in aquatic and soil ecosystems, phytotoxicity and bioaccumulation in agricultural crops. Chemosphere 96, 1-15.

Daunys, D., Zemlys, P., Olenin, S., Zaiko, A., Ferrarin, C., 2006. Impact of the zebra mussel Dreissena polymorpha invasion on the budget of suspended material in a shallow lagoon ecosystem. Helgoland Marine Research 60, 113-120.

Davis, T. W., Berry, D. L., Boyer, G. L., Gobler, C. J., 2009. The effects of temperature and nutrients on the growth and dynamics of toxic and non-toxic strains of Microcystis during cyanobacteria blooms. Harmful Algae 8, 715-725.

Ferrarin, C., Razinkovas, A., Gulbinskas, S., Umgiesser, G., Bliudziute L., 2008. Hydraulic regime-based zonation scheme of the Curonian Lagoon. Hydrobiologia 611, 133-146.

Galkus, A., Jokšas, K., 1997. Sedimentary material in the transitional aquasystem. Institute of Geography, Vilnius. 198 pp.

Garcia, A. C., Bargu, S., Dash, P., Rabalais, N. N., Sutor, M., Morrison, W., Walker, N. D., 2010. Evaluating the potential risk of microcystins to blue crab (Callinectes sapidus) fisheries and human health in a eutrophic estuary. Harmful Algae 9, 134-143.

Geis-Asteggiante, L., Lehotay, S. J., Fortis, L. L., Paoli, G., Wijey, C., Heinzen, H., 2011. Development and validation of a rapid method for microcystins in fish and comparing LC-MS/MS results with ELISA. Analytical and Bioanalytical Chemistry 401, 2617-2630. 
Heisler, J., Gilbert, P. M., Burkholder, J. M., Anderson, D. M., Cochlan, W., Dennison, W. C., Dortch, Q., Gobler, C. J., Heil, C. A., Humphries, E., Lewitus, A. J., Magnien, R., Marshall, H. G., Sellner, K., Stockwell, D. A., Suddleson, M., 2011. Eutrophication and harmful algal blooms. Harmful Algae 8, 3-13.

Ibelings, B. W., Backer, L. C., Kardinaal, E., Chorus, I., 2014. Current approaches to cyanotoxin risk assessment and risk management around the globe. Harmful Algae 40, 63-74.

Ibelings, B. W., Bruning, K., de Jonge, J., Wolfstein, K., Pires, L. M. D., Postma, J., Burger, T., 2005. Distribution of microcystins in a lake foodweb: No evidence for biomagnification. Microbial Ecology 49, 487-500.

Ibelings, B. W., Chorus, I., 2007. Accumulation of cyanobacterial toxins in freshwater "seafood" and its consequences for public health: a review. Environmental Pollution 150, 177-192.

Jaanus, A., Andersson, A., Olenina, I., Toming, K., Kaljurand, K., 2011. Changes in phytoplankton communities along a north-south gradient in the Baltic Sea between 1990 and 2008. Boreal Environmental Research 16, 191-208.

Kankaanpaa, H. T., Sjovall, O., Huttunen, M., Olin, M., Karlsson, K., Hyvarinen, K., Sneitz, L., Harkonen, J., Sipia, V. O., Meriluoto, J. A. O., 2009. Production and sedimentation of peptide toxins nodularin-R and microcystin-LR in the northern Baltic Sea. Environmental Pollution 157, 1301-1309.

Karjalainen, M., Engström-Ost, J., Korpinen, S., Peltonen, H., Pääkkönen, J.P., Rönkkönen, S., Suikkanen, S., Viitasalo, M., 2007. Ecosystem consequences of cyanobacteria in the northern Baltic Sea. Ambio 36, 195-202.

Kozlowsky-Suzuki, B., Wilson, A. E., Ferrão-Filho, A. da S., 2012. Biomagnification or biodilution of microcystins in aquatic foodwebs? Meta-analyses of laboratory and field studies. Harmful Algae 18, 47-55.

Lehman, P. W., Teh, S. J., Boyer, G. L., Nobriga, M. L., Bass, E., Hogle, C., 2010. Initial impacts of Microcystis aeruginosa blooms on the aquatic food web in the San Francisco Estuary. Hydrobiologia 637, 229-248.

Lesutiene, J., Bukaveckas, P. A., Gasiunaite, Z. R., Pilkaityte, R., Razinkovas-Baziukas, A., 2014. Tracing the isotopic signal of a cyanobacteria Bloom through the food web of a Baltic Sea coastal lagoon. Estuarine, Coastal and Shelf Science 138, 47-56.

Mazur-Marzec, H., Sutryk, K., Kobos, J., Hebel, A., Holhfield, N., Blaszczyk, A., Torunska, A., Kaczkowska, M. J., Lysiak-Pastuszak, W., Jasser, I., 2013. Occurrence of cyanobacteria and cyanotoxin in the southern Baltic proper. Filamentous cyanobacteria versus singlecelled picocyanobacteria. Hydrobiologia 701, 235-2552.

Michalak, A. M., Anderson, E. J., Beletsky, D., Boland, S., Bosch, N. S., Bridgeman, T.B., Chaffin, J.D., Cho, K., Confesor, R., Daloğlu, I. and DePinto, J.V., 2013. Record-setting algal bloom in Lake Erie caused by agricultural and meteorological trends consistent with expected future conditions. Proceedings of the National Academy of Sciences 110, 64486452. 
Mikhailova, M. V., Zaromskis, R., 2013. Hydrological processes in the mouth area of the Nemunas (Neman) River. Water Resources 40, 97-110.

Miller, M. A., Kudela, R. M., Mekebri, A., Crane, D., Oates, S. C., Tinker, M. T., Staedler, M., Miller, W. S., Toy-Choutka, S., Dominik, G., Hardin, D., Langlois, G., Murray, M., Ward, K., Jessup, D. A., 2010. Evidence for a novel marine harmful algal bloom: cyanotoxin (microcystin) transfer from land to sea otters. PLoS One 5, e12576.

Misson, B., Donnadieu-Bernard, F., Godon, J.-J., Amblard, C., Latour, D., 2012. Short- and long- term dynamics of the toxic potential and genotypic structure in benthic populations of Microcystis. Water Resources 46, 1438-1446.

Neffling, M.-R., Lance, E., Meriluoto, J. A. O., 2010. Detection of free and covalently bound microcystins in animal tissues by liquid chromotagraphy-tandem mass spectrometry. Environmental Pollution 158, 948-952.

Olenina, I., Hajdu, S., Edler, L., Andersson, A., Wasmund, N., Busch, S., Göbel, J., Gromisz, S., Huseby, S., Huttunen, M., Jaanus, A., Kokkonen, P., Ledaine, I., Niemkiewicz, E., 2006. Biovolumes and size-classes of phytoplankton in the Baltic Sea. Baltic Sea Environmental Proceedings 106, 1-144.

O'Neil, J. M., Davis, T. W., Burford, M. A., Gobler, C. J., 2012. The rise of harmful cyanobacteria blooms: the potential roles of eutrophication and climate change. Harmful Algae 14, 313-334.

Paerl, H. W., Otten, T. G., 2013a. Harmful cyanobacterial blooms: Causes, consequences and controls. Microbial Ecology 65, 995-1010.

Paerl, H. W., Otten, T. G., 2013b. Blooms bite the hand that feeds them. Science 343, 433-434.

Paerl, HW., Huisman, J., 2009. Climate change: A catalyst for global expansion of harmful cyanobacterial blooms. Environmental Microbiology Reports 1, 27-37.

Paldaviciene, A., Mazur-Marzec, H., Razinkovas, A., 2009. Toxic cyanobacteria blooms in the Lithuanian part of the Curonian Lagoon. Oceanologia 51, 203-216.

Paldaviciene, A., Zaiko, A., Mazur-Marzec, H., Razinkovas-Baziukas, A., 2015. Bioaccumulation of microcystins in invasive bivalves: a case study from the boreal lagoon ecosystem. Oceanologia 57, 93-101.

Poste, A. E., Hecky, R. E., Guilidford, S. J., 2011. Evaluating microcystin exposure risk through fish consumption. Environmental Science and Technology 45, 5806-5811.

Preece, E. P., Moore, B. C., Swanson, M. F., Hardy, F. J., 2015. Identifying best methods for routine ELISA detection of microcystin in seafood. Environmental Monitoring and Assessment 187, DOI 10.1007/x10661-014-4255-y.

Rastogi, R. P., Sinha, R. P., Incharoensakdi, A., 2014. The cyanotoxin-microcystins: current overview. Reviews in Environmental Science and Biotechnology 13, 215-249.

Schaus, M. H., Vanni, M. J., Wissing, T. E., 2002. Biomass-dependent diet shifts in omnivorous gizzard shad: Implications for growth, foodweb, and ecosystem effects. Transactions of the American Fisheries Society 131, 40-54. 
Schmidt, J. R., Wilhelm, S. W., Boyer, G. L., 2014. The fate of microcystins in the environment and challenges for monitoring. Toxins 6, 3354-3387.

Silva-Stenico, M. E., CantúsioNeto, R., Alves, I. R., Moraes, L. A. B., Shishido, T. K., Fiore, M. F., 2009. Hepatotoxin microcystin-LR extraction optimization. Journal of the Brazilian Chemical Society 20, 535-542.

Smith, J. L., Boyer, G.L., Mills, E.L., Schulz, K.L., 2008. Toxicity of Microcystin-LR, a cyanobacterial toxin, to multiple life stages of the burrowing mayfly, Hexagenia, and possible implications for recruitment. Environmental Toxicology 23, 499-506.

Smock, L. A., Wright, A. B., Benke, A. C., 2005. Atlantic Coast Rivers of the southeastern United States. In Rivers of North America. Benke, A. C., Cushing, C. E., Eds., Elsevier Academic Press, pp 73-122.

Takahashi, T., Umehara, A., Tsutsumi, H., 2014. Diffusion of microcystins (cyanobacteria hepatotoxins) from the reservoir of Isahaya Bay, Japan, into the marine and surrounding ecosystems as a result of large-scale drainage. Marine Pollution Bulletin 89, 250-258.

World Health Organization. 2003. Guidelines for Safe Recreational Water Environments, Coastal and Fresh Waters, Geneva, Vol. 1, p 219.

Wilson, A. E. W. A., Gossiaux, D. C. G. D., Höök, T. O. H. T., Berry, J. P. B. J., Landrum, P. F. L. P., Dyble, J. D., Stephanie, J., Guildford, G. S., 2008. Evaluation of the human health threat associated with the hepatotoxin microcystin in the muscle and liver tissues of yellow perch (Perca flavescens). Canadian Journal of Fisheries and Aquatic Sciences 65, 1487-1497.

Wood, J. D., Bukaveckas P. A., 2014. Increasing severity of phytoplankton nutrient limitation following reductions in point source inputs to the tidal freshwater segment of the James River Estuary. Estuaries and Coasts 37, 1188-1201.

Wood, J. D., Elliott, D., Garman, G. C., Hopler, D., Lee, W., McInich, S. P., Porter, A.J., Bukaveckas, P. A., 2016. The role of consumers in influencing trophic state and the fate of primary production in the James River Estuary, Virginia. Food Webs 7, 1-12.

Wood, J. D., Franklin, R. B., Garman, G. C., McInich, S. P., Porter, A. J., Bukaveckas, P. A., 2014. Exposure to the cyanotoxin microcystin arising from inter-specific differences in feeding habits among fish and shellfish from the James River Estuary, Virginia. Environmental Science and Technology 48, 5194-5202.

Zemlys P., Ferrarin C., Umgiesser G., Gulbinskas S., Bellafiore D., 2013. Investigation of saline water intrusions into the Curonian Lagoon (Lithuania) and two-layer flow in the Klaipeda Strait using finite element hydrodynamic model. Ocean Science 9, 573-584.

Zhang, D., Xie, P., Liu, Y., Qiu, T., 2009. Transfer, distribution and bioaccumulation of microcystins in the aquatic food web in Lake Taihu, China, with potential risks to human health. Science of the Total Environment 407, 2191-2199.

Zilius, M., Bartoli, M., Bresciani, M., Katarzyte, M., Ruginis, T., Petkuviene, J., Lubiene, I., Giardino, C., Bukaveckas, P. A., de Wit, R., Razinkovas-Baziukas, A., 2014. Feedback 
mechanisms between cyanobacterial blooms, transient hypoxia, and benthic phosphorus regeneration in shallow coastal environments. Estuaries and Coasts 37, 680-694. 
552 Table 1.Site characteristics of the James River Estuary and the Curonian Lagoon (JTF = James 553 Tidal-Fresh segment; NCL = Northern Curonian Lagoon; Bukaveckas et al. 2011, Bukaveckas 554 and Isenberg 2013, Ferrarin et al. 2008, Bresciani et al. 2012, Zemlys et al. 2013).

555

\begin{tabular}{lcc}
\hline & James River Estuary & Curonian Lagoon \\
\hline Surface Area $\left(\mathrm{km}^{2}\right)$ & 604 & 1,584 \\
Mean Depth $(\mathrm{m})$ & 3.5 & 3.8 \\
Salinity $(\mathrm{ppt})$ & 0.1 to $20(<0.5$ in JTF $)$ & 0.1 to 7 \\
Principal Tributary & $\begin{array}{c}\text { James River }(92 \% \text { of } \\
\text { total runoff })\end{array}$ & $\begin{array}{c}\text { Nemunas River }(96 \% \text { of } \\
\text { total runoff) }\end{array}$ \\
$\begin{array}{l}\text { Riverine Inputs } \\
\left(\mathrm{m}^{3} \mathrm{~s}^{-1}\right)\end{array}$ & 227 & 698 \\
$\begin{array}{l}\text { Freshwater } \\
\text { Replacement Time }(\mathrm{d})\end{array}$ & $15-25(\mathrm{JTF}$ in Summer $)$ & up to $80(\mathrm{NCL})$ \\
Summer CHLa $\left(\mu \mathrm{g} \mathrm{L}{ }^{-1}\right)$ & $30-60(\max \sim 100)$ & $>40(\max >400)$ \\
\hline
\end{tabular}


557 Table 2. Estimated daily ingestion (EDI) of microcystin via consumption of fish and shellfish 558 from the Curonian Lagoon and James River Estuary (*denotes commercially and recreationally 559 important species). EDIs were derived for a single serving on one day (300 g wm) and for long560 term consumption based on one serving per week. Microcystin (MC) concentrations are for 561 muscle tissue, except in Blue Crabs, for which consumption was based on $80 \%$ muscle and $20 \%$ 562 viscera.

563

\begin{tabular}{|c|c|c|c|c|c|c|}
\hline \multirow[t]{2}{*}{ Site } & \multirow[t]{2}{*}{ Common Name } & \multicolumn{3}{|c|}{ Tissue MC (ng/gww) } & \multicolumn{2}{|c|}{$E D I(\mu g M C / d)$} \\
\hline & & $\mathbf{N}$ & Mean & SE & $1 \operatorname{sen} / d$ & $1 \mathrm{serv} / \mathrm{wl}$ \\
\hline \multirow[t]{8}{*}{ Curonian Lagoon } & Bream*' & 40 & 11 & 10 & 3.4 & 0.49 \\
\hline & Bleak & 27 & 82 & 62 & 24.5 & 3.49 \\
\hline & European Perch" & 40 & 4 & 2 & 11 & 0.16 \\
\hline & European Perch (juv) & 56 & 10 & 8 & 29 & 0.42 \\
\hline & Roach* & 39 & 10 & 16 & 3.0 & 0.42 \\
\hline & Roach (juv) & 35 & 14 & 8 & 4.3 & 0.61 \\
\hline & Sabre Carp* & 29 & 12 & 8 & 3.7 & 0.53 \\
\hline & Pikeperdh* & 32 & 5 & 3 & 15 & 0.22 \\
\hline \multirow[t]{7}{*}{ James River Estuary } & Atlantic Menhaden" & 23 & 0.7 & 0.6 & 0.2 & 0.03 \\
\hline & Blue Crab Musde* & 36 & 4 & 2 & \multirow{2}{*}{23} & \multirow{2}{*}{0.66} \\
\hline & Blue Crab Viscera* & 36 & 24 & 4 & & \\
\hline & Blue Catfi sh $(0-20$ am)* & 26 & 0.9 & 0.5 & 0.3 & 0.04 \\
\hline & Gzzard Shad (adult) & 60 & 0.3 & 0.1 & 0.1 & 0.01 \\
\hline & Gzzard Shad (juv) & 32 & 0.5 & 0.2 & 0.1 & 0.02 \\
\hline & Threadifi n Shad & 42 & 10 & 0.2 & 0.3 & 0.04 \\
\hline
\end{tabular}


Figure 1. Sampling locations within the James River Estuary and the Curonian Lagoon. Circles denote water and sediment sampling sites; triangles are fish-shellfish sampling sites; the square is a long-term phytoplankton monitoring station for the Environmental Protection Agency of Lithuania.
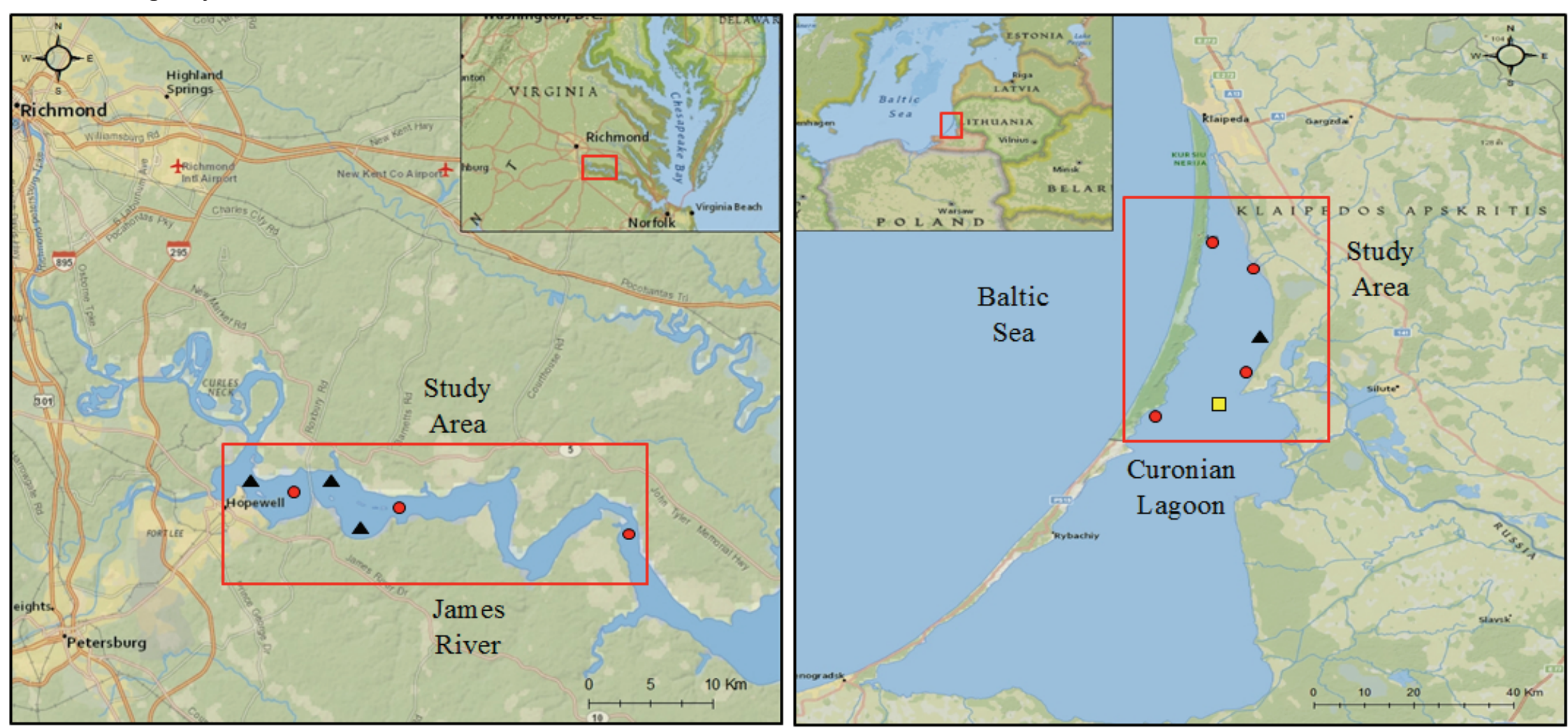
571 Figure 2. Seasonal and interannual variation in chlorophyll-a, temperature and cyanobacteria 572 biomass in the Curonian Lagoon during 2006-2014. Discharge data for the principal tributary 573 (Nemunas River) were provided by the Lithuanian Hydrometeorological Service.

574
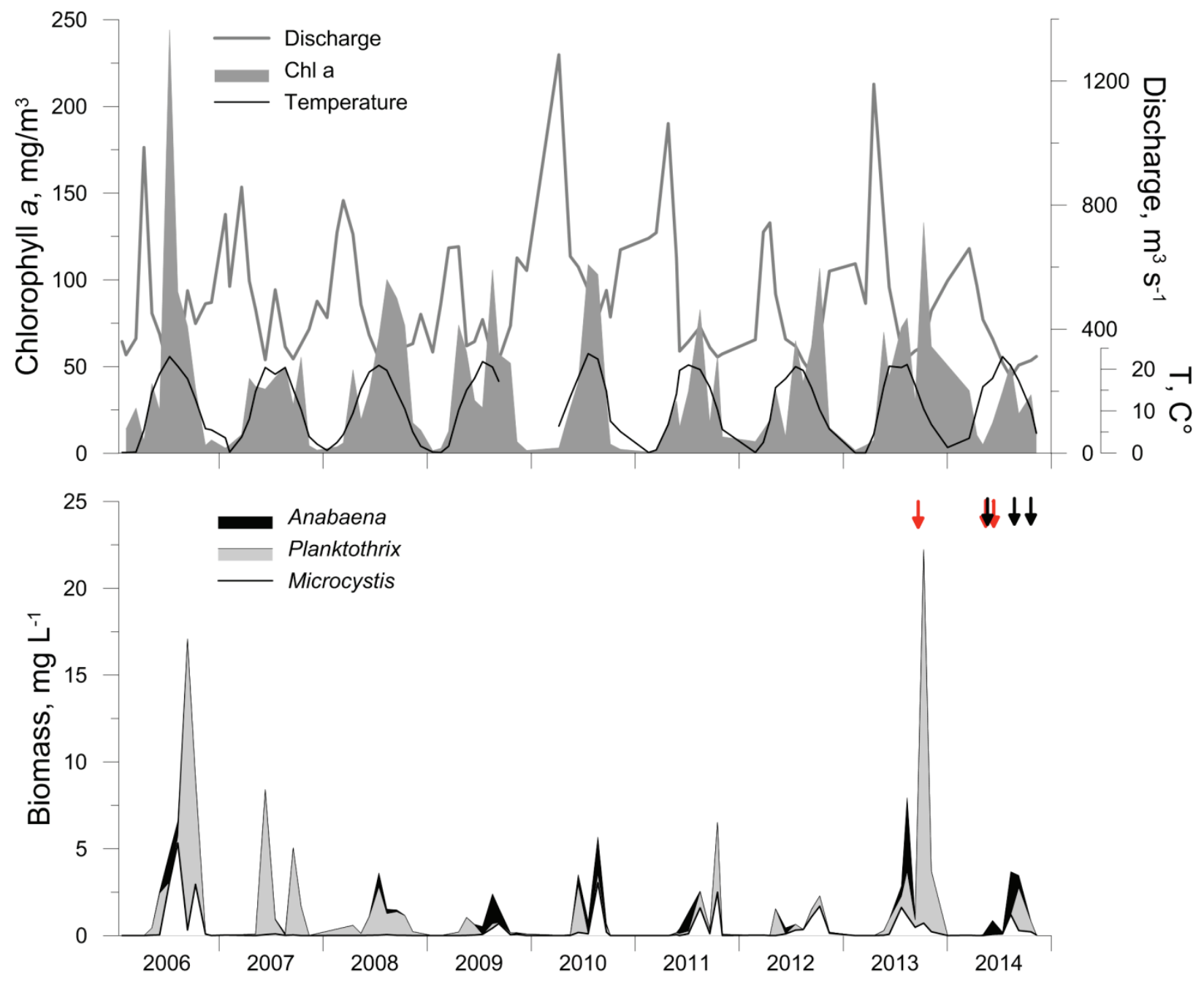
576 Figure 3. Chlorophyll (CHLa) and microcystin (MC) concentrations in the Curonian Lagoon 577 (2013-14) and the James River Estuary (2012-13). Values represent means for 4 (CL) and 3 578 (JRE) sampling locations (with standard error).

579

580



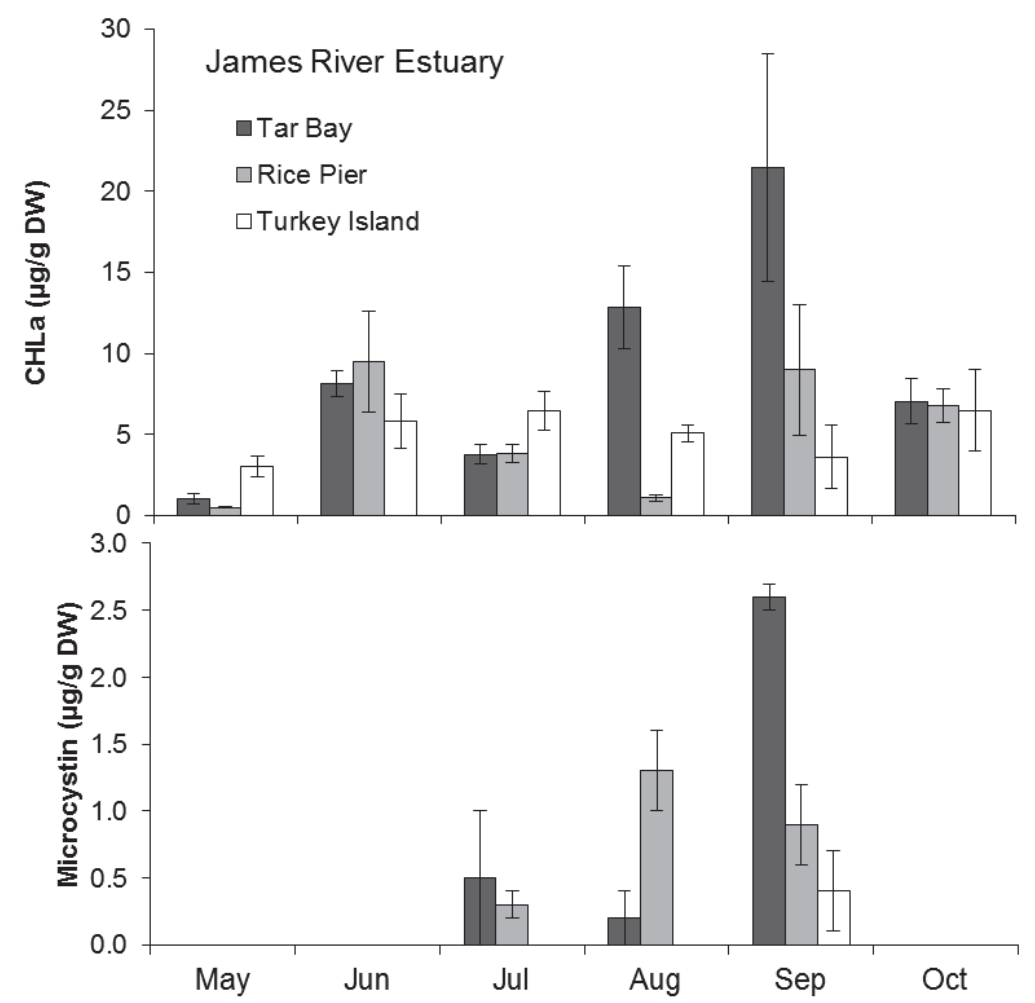

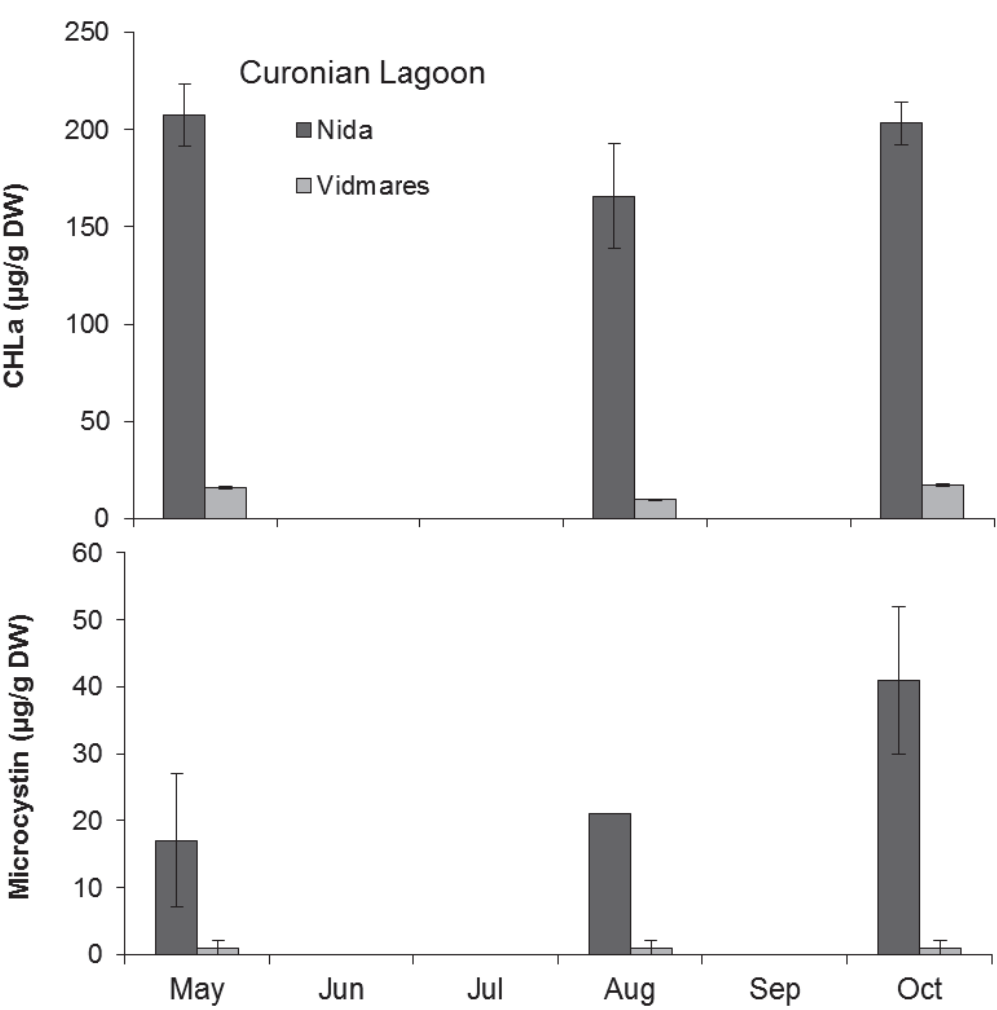

Figure 4. Chlorophyll-a (CHLa) and microcystin concentrations of surficial sediments $(0-2 \mathrm{~cm})$ from the James River Estuary and the Curonian Lagoon (note difference in y-axis scales). Curonian Lagoon sediments were sampled in May, August and October only. Values represent means for three replicate cores (with standard error) from each sampling location. 
Figure 5. Comparison of microcystin concentrations in water/seston, sediment and biota of the James River Estuary and the Curonian Lagoon. Fish data are based on concentrations found in the liver; data for invertebrates are for viscera (mean $\pm \mathrm{SE}$ ). Sediment and biological data are mass-specific (ng $\left.\mathrm{MCg}^{-1} \mathrm{dm}\right)$; water data are volumetric (ng $\mathrm{MC} \mathrm{L}^{-1}$ ).

591
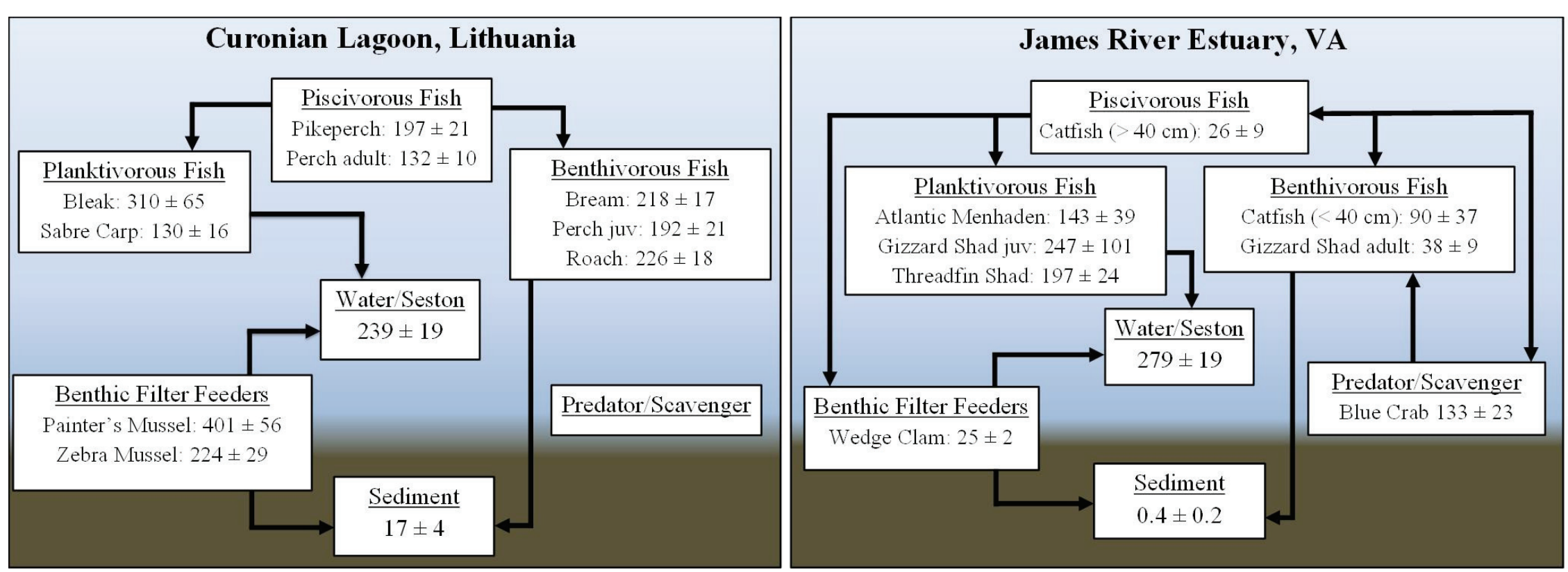

601
Figure 6. Microcystin concentrations in liver tissues of fishes from the Curonian Lagoon and James River Estuary. Benthic omnivores: juvenile Blue Catfish (Cat), adult Gizzard Shad (Gz), Bream (Br), juvenile Perch (jPe), Roach (Ro), juvenile Roach (jRo). Predators: adult Blue Catfish (C40), Blue Crabs (Crb), Zander (Zan), adult Perch (Pe). Planktivores: juvenile Gizzard Shad (jGz), Atlantic Menhaden (Men), Threadfin Shad (Thr), Bleak (Blk), and Sabre Carp (Carp). The line within each box represents the median, box boundaries are 25 th and 75 th percentiles, whiskers are 10th and 90th percentiles, and points are outliers.

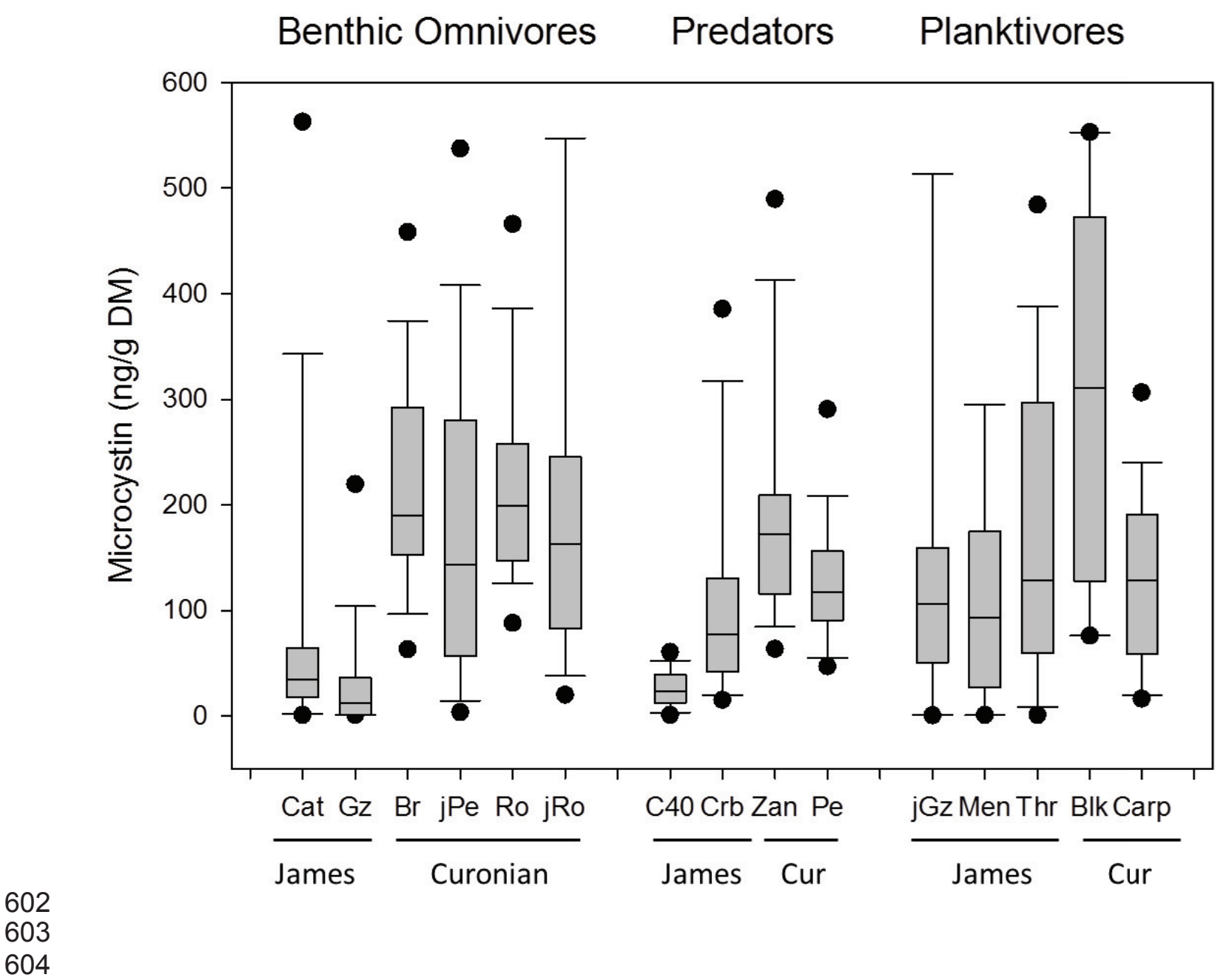


604 Figure 7. Seasonal variation in microcystin (MC) content of fish-shellfish from the Curonian 605 Lagoon and James River Estuary. Fish data are for liver tissues; Blue Crab values are for 606 viscera. Blue Catfish data are for juveniles $(<40 \mathrm{~cm})$. P values are for 1-way ANOVAs testing 607 for seasonal differences.

608
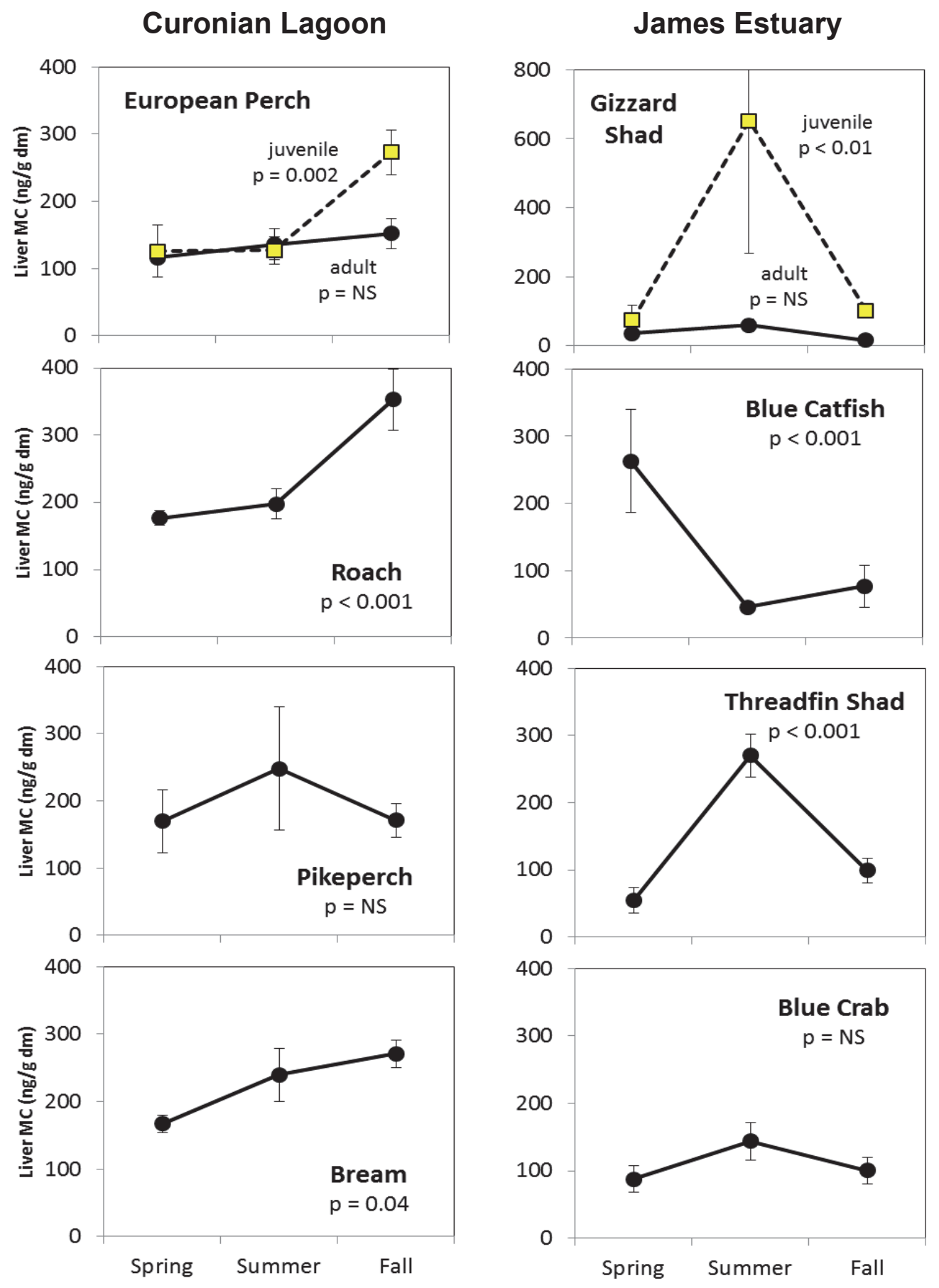